\title{
Koronawirus a narząd wzroku. Możliwości zakażenia, objawy kliniczne i profilaktyka w gabinecie okulistycznym
}

\author{
Coronavirus and the eyes. The possibilities of infection transmission, clinical symptoms \\ and prophylaxis in the ophthalmic office
}

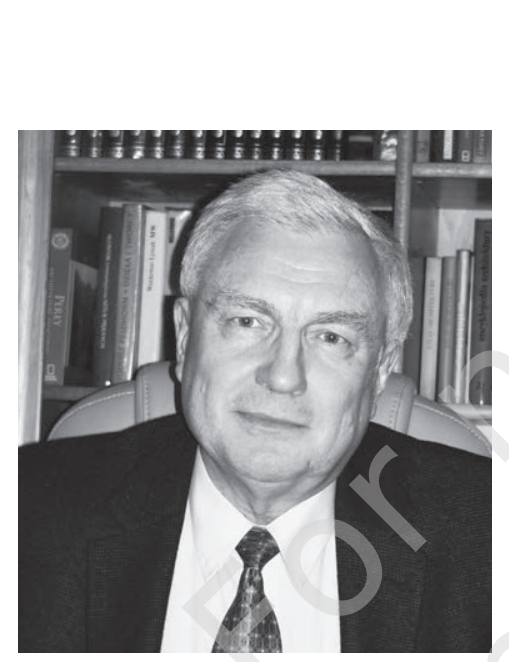

N A J W A Ż N IE J S ZE

Okuliści znajdują się w grupie podwyższonego ryzyka

zakażeniem wirusem SARS-

-CoV-2 ze względu na bliski kontakt z pacjentem w trakcie badania oczu. Dlatego powinny być przestrzegane szczególne zasady profilaktyczne dotyczące ograniczenia ryzyka zakażenia pacjentów i personelu medycznego.

\section{H I G H L I G H T S}

Ophthalmologists are at increased risk of being infected with SARS-CoV-2 virus due to their close contact with a patient during an eye examination. Therefore, specific preventive measures regarding the reduction of risk of infection both in patients and in medical staff should be put into use.
Marek E. Prost

Klinika Okulistyczna,

Wojskowy Instytut Medycyny Lotniczej w Warszawie Kierownik: p.o. dr n. med. Jaromir Wasyluk Centrum Okulistyki Dziecięcej w Warszawie Kierownik: dr n. med. Ewa Oleszczyńska-Prost

Pamięci Doktora Li Wenlianga, lekarza okulisty z Wuhanu, Chiny, który jako pierwszy poinformowat o możliwym wybuchu epidemii koronawirusa. Doktor Wenliang zarazit się wirusem, badajac pacjenta z jaskra, i zmart 7 lutego 2020 r. w wieku 34 lat.

In memory of Dr. Li Wenliang, an ophthalmologist from Wuhan, China, who was the first to inform about a possible outbreak of the coronavirus epidemic. Doctor Wenliang became infected with a virus while examining a patient with glaucoma and died on February $7^{\text {th }}, 2020$ at the age of 34.

\section{STRESZCZENIE}

Wirus SARS-CoV-2 poza zapaleniem spojówek nie powoduje zmian w narządzie wzroku. Powierzchnia oczu jest jednak jedną z głównych dróg przedostawania się wirusa do organizmu człowieka, co wymaga zastosowania specjalnych metod ochrony oczu, zarówno u chorych, jak i personelu medycznego. W pracy zostaną przedstawione zalecenia odnośnie do profilaktyki w gabinetach okulistycznych ze szczególnym uwzględnieniem problemu przygotowania aparatów do badania i sterylizacji końcówek urządzeń diagnostycznych.

Słowa kluczowe: koronawirus, objawy kliniczne, profilaktyka w okulistyce

\section{ABSTRACT}

Apart from conjunctivitis, SARS-CoV-2 virus does not affect the eyes. However, it remains one of the main routes for the virus to enter the human body, so special methods of eye protection both for patients and medical personnel are necessary. The paper presents recommendations for eye protection in ophthalmic practices with special attention to the problem of preparing the equipment for examination and sterilization of diagnostic equipment.

Key words: coronavirus, clinical symptoms, prophylaxis in ophthalmology 


\section{WSTĘP}

11 marca 2020 r. WHO ogłosiła stan pandemii choroby COVID-19. Choroba ta jest spowodowana wirusem SARS-CoV-2, należącym do grupy koronawirusów. To wirus osłonkowy, którego genom stanowi jednoniciowe RNA o dodatniej polarności. U zakażonych pacjentów został on wykryty w wydzielinie z nosa i gardła, w plwocinie, stolcu, cieczy łzowej i krwi [1-3]. Uważa się, że głównymi wrotami zakażenia są: jama ustna, jama nosa i powierzchnia oka. Oczy to jeden z narządów, które są najbardziej narażone na kontakt z tym wirusem.

Celem niniejszego opracowania jest zapoznanie lekarzy okulistów ze zmianami, jakie wirus SARS-CoV-2 może powodować w narządzie wzroku, i z tym, jakie procedury profilaktyczne mogą oni przedsięwziąć w swoich gabinetach.

\section{OBJAWY KLINICZNE CHOROBY COVID-19 W NARZĄDZIE WZROKU}

Wirus SARS-CoV-2 powoduje na szczęście bardzo mało zmian w narządzie wzroku. Jedynym objawem, który stwierdzono u ludzi, jest surowicze zapalenie spojówek. Zapalenie to występuje rzadko. W opublikowanym niedawno artykule poinformowano o występowaniu zapalenia spojówek tylko u $0,8 \%$ chorych z potwierdzoną klinicznie chorobą COVID-19 wśród 1099 pacjentów leczonych w 30 szpitalach w Chinach [4]. W innym badaniu stany zapalne spojówek stwierdzono u 3\% leczonych, ale materiał kliniczny stanowiło tylko 30 chorych [2]. Zapalenie spojówek odnotowano również w przebiegu infekcji innymi gatunkami wirusa SARS-CoV-2 [5, 6]. Stany zapalne zazwyczaj nie są mocno nasilone i w większości przypadków ustępują samoistnie. W badaniach doświadczalnych obserwowano występowanie zapalenia spojówek i rogówek u szczurów po zakażeniu koronawirusem [7]. Zapalenie siatkówki i naczyniówki stwierdzono po wstrzyknięciu wewnątrzgałkowym wirusów u myszy [8]. Należy jednak zaznaczyć, że w badaniach tych czynnikiem zakaźnym były inne niż SARS-CoV-2 gatunki rodziny koronawirusów. Zapaleń rogówki nie stwierdzono u ludzi [2, 4].

Podsumowując, wirus SARS-CoV-2 poza zapaleniem spojówek nie powoduje zmian w narządzie wzroku. Oczy są jednak jedną z głównych dróg przedostawania się wirusa do organizmu człowieka, co wymaga specjalnych metod ich ochrony, zarówno u chorych, jak i personelu medycznego. Obecnie nie ma leczenia ogólnego o potwierdzonej skuteczności w terapii choroby COVID-19. Obserwacje przeprowadzone w trakcie epidemii w Hiszpanii wskazują, że niektóre leki przeciwwirusowe zmniejszają ciężkość przebiegu zakażenia, ale są to tylko dane oparte na odczuciach lekarzy [9].

Leczenie zapalenia spojówek jest objawowe (sztuczne łzy). Brakuje danych odnośnie do skuteczności miejsco- wych leków przeciwwirusowych (acyklowir, gancyklowir). W przypadku nadkażenia bakteryjnego można zastosować antybiotyki miejscowo.

Lekarze okuliści muszą się również liczyć z częstszym zgłaszaniem się chorych z zapaleniami spojówek, zaniepokojonych, czy nie jest to objaw choroby COVID-19. Zwiększa to prawdopodobieństwo, że spośród pracowników służby zdrowia personel okulistyczny będzie jednym z pierwszych mających kontakt z potencjalnie zakażonymi osobami.

W lutym 2020 r. w Chinach do leczenia choroby COVID-19 wprowadzono chlorochinę, lek pierwotniakobójczy stosowany w leczeniu malarii i pełzakowicy. Chorochina jest produkowana w Polsce. Parę dni temu Urząd Rejestracji Produktów Leczniczych, Wyrobów Medycznych i Produktów Biobójczych wydał pozytywną decyzję w sprawie zmiany dotyczącej pozwolenia na dopuszczenie do obrotu dla produktu leczniczego Arechin (chlorochina, czyli Chloroquini phosphas) polegającej na dodaniu nowego wskazania terapeutycznego: „Leczenie wspomagające w zakażeniach koronawirusami typu beta takimi jak SARS-CoV, MERS-CoV i SARS-CoV-2” oraz związanego z nim "dawkowania produktu leczniczego". Ponieważ ma on wiele często występujących działań niepożądanych w zakresie narządu wzroku, okuliści muszą się liczyć z tym, że pacjenci leczeni chlorochiną będą się obecnie o wiele częściej zgłaszać na badania wzroku [10]. Do tej pory lekarz okulista wyjątkowo rzadko miał możliwość badania pacjentów leczonych na malarię po pobycie w krajach tropikalnych. Działania niepożądane chlorochiny dotyczące narządu wzroku przedstawiono w tabeli 1.

\section{ZALECENIA ODNOŚNIE DO PROFILAKTYKI W OKRESIE PANDEMII INFEKCJI WIRUSEM SARS-COV-2 W GABINETACH OKULISTYCZNYCH}

\section{Ogólne zasady postępowania epidemiologicznego i medycznego}

Bardzo duża zakaźność wirusa SARS-CoV-2 i niewielkie objawy kliniczne powodują, że problemem dla okulistycznej służby zdrowia nie jest leczenie zmian w oczach, lecz profilaktyka zakażeń wśród pacjentów i personelu medycznego. Część z nich to zasady ogólne dotyczące każdego obywatela (zachowanie odległości 1-1,5 m od innych osób, częste mycie [stwierdzono, że mydła niszczą białkową osłonkę wirusa] i dezynfekcja rąk [szczególnie po korzystaniu z toalet, przygotowywaniu jedzenia, kontakcie ze zwierzętami i zabiegach pielęgnacyjnych dzieci i osób starszych], zakrywanie ust i nosa podczas kaszlu i kichania [ale nie dłońmi], unikanie dotykania oczu, nosa i ust, dbanie o odporność i kondycję fizyczną, wysypianie się, racjonalne odżywianie) i każdej placówki służby zdrowia (ograniczenie przyjęć do pilnych przypadków, umawianie wizyt pacjentów w różnych godzinach, aby zmniejszyć możliwość ich kontaktu ze 


\begin{tabular}{|c|c|c|c|c|}
\hline $\begin{array}{c}\text { Częstość } \\
\text { występowania }\end{array}$ & Objawy w narządzie wzroku & Uwagi & Diagnostyka & Leczenie \\
\hline Często & $\begin{array}{l}\text { Światłowstręt, zaburzenia widzenia } \\
\text { barw, upośledzenie akomodacji, mroczki } \\
\text { centralne, zawężenie pola widzenia. } \\
\text { W rogówce dochodzi do odkładania się } \\
\text { złogów. Zmiany w siatkówce występują } \\
\text { w okolicy plamki w postaci ognisk } \\
\text { odbarwień (zniesienie refleksu z plamki } \\
\text { - bawole oko), zwyrodnienia siatkówki, } \\
\text { zwężenia naczyń siatkówkowych, zaniku } \\
\text { nerwu wzrokowego. }\end{array}$ & $\begin{array}{l}\text { Występowanie } \\
\text { uszkodzeń narządu } \\
\text { wzroku związane } \\
\text { jest z wielkością } \\
\text { dawki i czasem } \\
\text { stosowania } \\
\text { preparatu. }\end{array}$ & $\begin{array}{l}\text { Wczesna obserwacja } \\
\text { i regularna kontrola } \\
\text { okulistyczna. } \\
\text { W badaniach } \\
\text { kontrolnych przydatne } \\
\text { są: testy Amslera, testy } \\
\text { widzenia barw, badanie } \\
\text { dna oka, badanie } \\
\text { pola widzenia, OCT, } \\
\text { elektroretinografia. }\end{array}$ & $\begin{array}{l}\text { Objawy } \\
\text { w rogówce } \\
\text { znikają po } \\
\text { odstawieniu } \\
\text { leku, natomiast } \\
\text { uszkodzenia } \\
\text { siatkówki mają } \\
\text { zazwyczaj } \\
\text { charakter } \\
\text { trwały. }\end{array}$ \\
\hline
\end{tabular}

sobą, zachowanie odległości 1-1,5 m w czasie rejestracji, pobytu w poczekalni, ograniczenie liczby osób towarzyszących choremu w poczekalni i w czasie badania, możliwość telefonicznego wzywania pacjentów oczekujących przed budynkiem przychodni [np. w samochodach], wstępny wywiad w czasie rejestracji odnośnie do przebytych chorób układu oddechowego i podróży zagranicznych w ostatnich 2 tygodniach przez pacjentów i ich rodziny, zapewnienie możliwości mycia rąk i ewentualnej ich dezynfekcji przed wizytą i po niej w gabinecie lekarskim, zabezpieczenie personelu medycznego w środki ochrony indywidualnej jednorazowego użycia, dezynfekcja pomieszczeń) [9].

\section{Szczegółowe zalecenia odnośnie do profilaktyki w gabinetach okulistycznych}

Okuliści są szczególnie narażani na zakażenie wirusem SARS-CoV-2 ze względu na bliski kontakt $\mathrm{z}$ pacjentem $\mathrm{w}$ trakcie badania, np. w czasie wziernikowania, ręcznej tonometrii itp. Stosowane są również różne przyrządy, których końcówki są w bezpośrednim kontakcie z powierzchnią oka (tonometry, biometry, aparaty USG). Dlatego też $\mathrm{w}$ trakcie pobytu pacjenta $\mathrm{w}$ gabinecie i jego badania powinny być przestrzegane szczególne zasady profilaktyczne, które istotnie wpłyną na ograniczenie ryzyka zakażenia [9]:

- Wywiad i rozmowa z pacjentem powinny się odbywać z zachowaniem odległości przynajmniej 1,5 m.

- Należy poinformować pacjentów, aby nie odzywali się w trakcie badania okulistycznego do lekarza lub pielęgniarki. Dotyczy to również personelu medycznego.

- W trakcie rozmowy z pacjentem i badania personel medyczny powinien stosować środki osobistej ochrony ust, nosa i oczu. Szczególnie ważna dla lekarzy okulistów jest ochrona oczu, ponieważ stanowią one jedno z głównych wrót wnikania wirusa do organizmu człowieka, zaś niektóre badania wykonywane są w bardzo bliskiej odległości między oczami badającego a ba- danego. Osłony twarzy, przyłbice i okulary ochronne, używane przez stomatologów, są bardzo niewygodne i praktycznie uniemożliwią np. badanie dna oka. Badania te mogą być jednak przeprowadzane przy zastosowaniu okularów korekcyjnych, które zapewniają gorszą ochronę, ale dzięki nim można je wykonać.

- Bardzo ważne jest również zastosowanie przesłon w trakcie badań, w których przebiegu pacjent i lekarz siedzą naprzeciw siebie, np. w trakcie badania w lampie szczelinowej. Produkowane dawniej lampy szczelinowe były wyposażone w plastikowe ekraniki podwieszone pod okularami. Obecnie większość sprzedawanych urządzeń tego typu nie ma fabrycznych przesłon. Poza tym zazwyczaj są one za małe i nie zapewniają należytej osłony przed zakażeniem. Dlatego lepiej wykonać je samodzielnie, np. ze sztywnej koszulki na dokumenty A4 (ofertówki), którą można kupić w każdym sklepie papierniczym, i po wykonaniu otworu w górnej części zamontować ją między okularem a korpusem lampy szczelinowej (ryc. 1). Przesłony takie mają dużą powierzchnię i dobrze oddzielają pacjenta i lekarza, a poza tym można je, np. codziennie, co pare godzin, wymienić na nowe (sprzedawane są w opakowaniach po 100 sztuk).

- Sterylizacja końcówek urządzeń diagnostycznych w gabinecie okulistycznym. Najlepszym rozwiązaniem jest stosowanie bezkontaktowych metod diagnostycznych, ale w przypadku technologii wykorzystujących podmuch powietrza (air puff) istnieje ryzyko, że podmuch powietrza może spowodować powstanie aerozolu łez wokół wokół oczu badanego pacjenta. Kiedy konieczne jest dotknięcie powierzchni oka, zaleca się stosowanie sterylnych jednorazowych końcówek (np. tonometry Goldmanna, iCare). W niektórych urządzeniach, w których np. nie ma wyjmowanych końcówek, istnieje możliwość użycia jednorazowych, sterylnych gumowych nakładek (np. tonometry Tonopen, Pachypen, 


\section{RYCINA 1 \\ Przesłona w lampie szczelinowej wykonana przez autora pracy z ofertówki A4.}
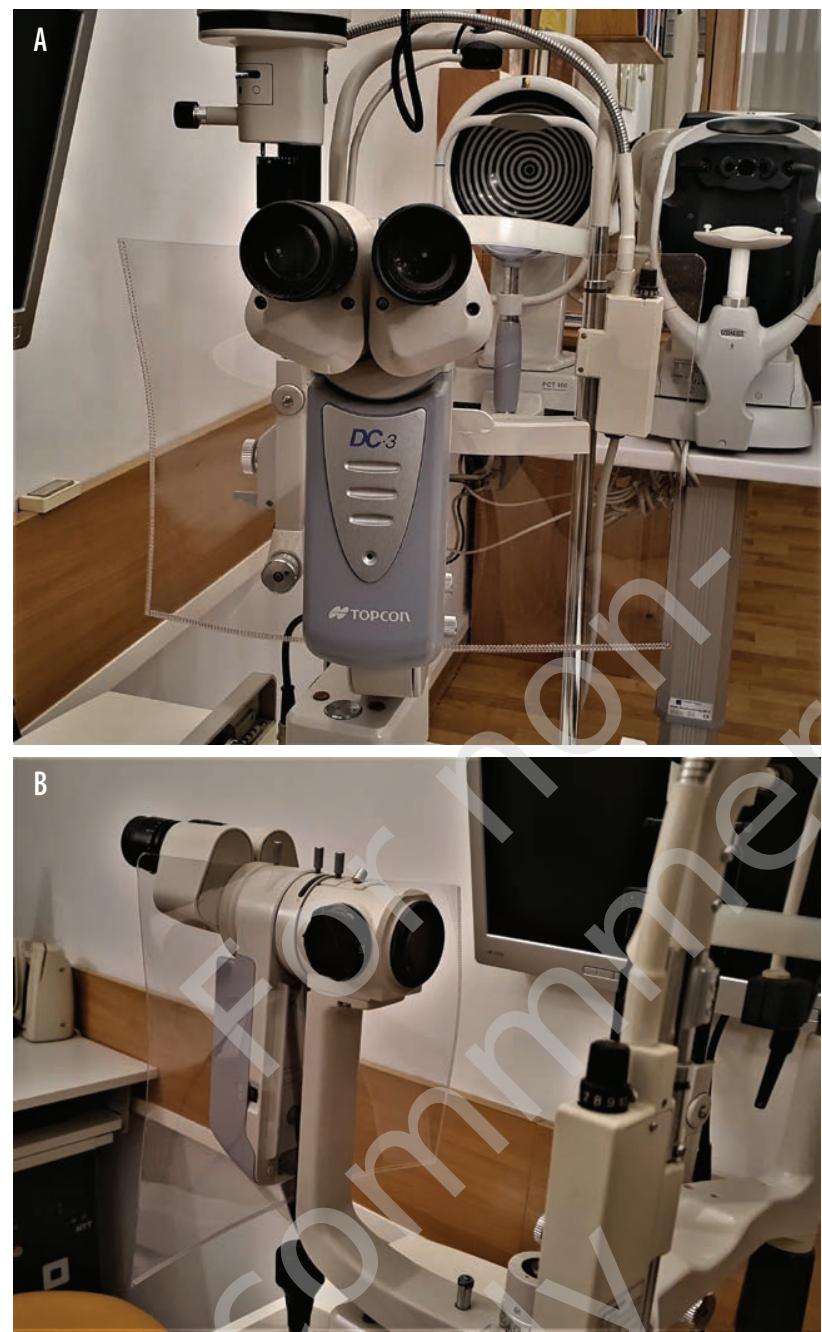

sondy ultradźwiękowe B, biometry). W czasie epidemii nie zapewniają one jednak wystarczającej ochrony przed zakażeniem. Należy jednak pamiętać, że pomimo stosowania np. jednorazowych końcówek powinno się dokładnie zdezynfekować po każdym pacjencie trzymaną w ręku głowicę oraz kable. Zalecana jest również dezynfekcja urządzeń mierzących w sposób bezkontaktowy po każdym badaniu (możliwość osadzenia się kropelek pary wodnej z ust chorego w czasie oddychania). W przypadku urządzeń okulistycznych nie możemy jednak użyć metod fizycznych (np. plazma, para wodna, różne rodzaje promieniowania). Konieczne jest więc zastosowanie metod chemicznych. Większość końcówek oraz aparatów wykonana jest jednak z tworzyw sztucznych i dlatego liczba środków chemicznych, które możemy zastosować, jest ograniczona. Mogą one bowiem powodować uszkodzenia powierzchni końcówek i sond oraz klejów łączących poszczególne części, co z kolei może prowadzić do uszkodzeń nabłonka ro- gówki i spojówek ułatwiających wnikanie wirusów do tkanek oka. Z tego powodu do dezynfekcji nie można stosować alkoholi, acetonu czy chloroksylenonu, które są rozpuszczalnikami dla tworzyw sztucznych. Najmniejsze uszkodzenia końcówek i sond powodują związki chloru (podchloryn sodu) i nadtlenek wodoru. Oba te związki mają przy tym szersze spektrum działania przeciwwirusowego niż np. 70\% alkohol etylowy lub izopropylowy. Po użyciu do dezynfekcji podchlorynu sodu i nadtlenku wodoru czasami obserwuje się powstanie półprzejrzystego filmu na powierzchni końcówki (można go usunąć za pomocą płynu do czyszczenia twardych soczewek kontaktowych). Jodopowidon ma szerokie spektrum działania przeciwwirusowego, ale jego dłuższe stosowanie może powodować przebarwienia powierzchni tworzyw sztucznych.

$\mathrm{Z}$ uwagi na to, że zakażenia wirusem $\mathrm{z}$ rodziny korona były do tej pory rzadkie i powodowały małe zmiany chorobowe, w piśmiennictwie brakuje danych, jak działają na niego różne środki dezynfekcyjne. Biorąc pod uwagę budowę koronawirusa, należy jednak sądzić, że jest on bardziej wrażliwy na działanie ww. środków niż np. adenowirusy. Dlatego też do dezynfekcji końcówek, sond, głowic i korpusów urządzeń okulistycznych najlepszym związkiem chemicznym jest podchloryn sodu 0,5\% [11]. Jest on produkowany najczęściej w stężeniu 15\%, rzadziej 5\%, i dlatego wymaga rozcieńczenia przed użyciem (tab. 2). Jest dość szeroko stosowany w naszym kraju, ale w oczyszczaniu i uzdatnianiu wód i ścieków, w przemyśle papierniczym, włókienniczym, tekstylnym oraz farmaceutycznym i medycznym, a jego produkcja w Polsce wynosi 150-200 t dziennie. Dlatego jest on dostępny w hurtowniach i sklepach chemicznych. W razie trudności w otrzymaniu podchlorynu sodu można użyć do dezynfekcji roztwór nadtlenku wodoru 10\% (woda utleniona). Należy jednak pamiętać, że dostępny w aptekach roztwór jest sprzedawany w stężeniu 3\%. Nie działa on wtedy na część wirusów, m.in. na adenowirusy. Działanie takie ma dopiero roztwór 10\%. Wyższe stężenia (np. najczęściej 12\%, rzadziej 30\%) stosowane są w głównej mierze we

\section{TABELA 2}

Przygotowanie i stosowanie roztworu podchlorynu sodu 0,5\% do dezynfekcji w gabinecie okulistycznym.

1. Przygotowanie roztworu $0,5 \%$ :

- $1 \mathrm{cz}$. podchlorynu $5 \%+9 \mathrm{cz}$. wody

- 1 cz. podchlorynu $15 \%+29 \mathrm{cz}$. wody

2. Stosowanie:

- czas moczenia: $10 \mathrm{~min}$

- płukanie w sterylnym roztworze $\mathrm{NaCl}$ 0,9\%: 1 min

- osuszenie 
fryzjerstwie i w kosmetologii w celach znanych szczególnie paniom. Dlatego do sterylizacji urządzeń okulistycznych należy zaopatrzyć się w roztwór nadtlenku wodoru $12 \%$ w sklepach z artykułami fryzjerskimi.

\section{PODSUMOWANIE}

Obecnie nie ma możliwości całkowitego wysterylizowania wszystkich przedmiotów i aparatów w gabinecie okulistycznym, zachowując przy tym ciągłość pracy z pacjentami. Przestrzeganie ww. zasad powinno jednak znacznie ograniczyć możliwość rozprzestrzeniania się choroby COVID-19 u naszych pacjentów i personelu medycznego.

\section{ADRES DO KORESPONDENCJI}

\section{prof. dr hab. n. med. Marek E. Prost}

Klinika Okulistyczna,

ORCID:

Marek E. Prost - ID - http://orcid.org/0000-0002-5620-4171

\section{Piśmiennictwo}

1. Holshue ML, DeBolt C, Lindquist S et al. Clinical characteristics of coronavirus disease 2019 in China. N Eng J Med. 2020; 382: 1-13. http://doi.org/10.1056/NEJMoa2001191.

2. Xia J, Tong J, Liu M et al. Evaluation of coronavirus in tears and conjunctival secretions of patients with SARS-CoV-2 infection. J Med Virol. 2020. http://doi.org/10.1002/jmv.25725.

3. Yeo C, Kaushal S, Yeo D. Enteric involvement of coronaviruses: is faecal - oral transmission of SARS-CoV-2 possible? Lancet Gastroenterol Hepatol. 2020; 5(4): 335-7. http://doi.org/10.1016/S2468-1253(20)30048-0.

4. Guan W, Ni Z, Hu Y et al. Clinical characteristics of coronavirus disease 2019 in China. N Eng J Med. 2020; 382. http://doi.org/10.1056/ NEJMoa2002032.

5. Vabret A, Mourez T, Dina J et al. Human coronavirus NL63, France. Emerg Infect Dis. 2005; 11(8): 1225-9.

6. van der Hoek L, Pyrc K, Jebbink MF et al. Identification of a new human coronavirus. Nat Med. 2005; 10(4): 368-73.

7. Lai YL, Jacoby RO, Bhatt PN et al. Keratoconjunctivitis associated with sialodacryoadenitis in rats. Invest Ophthalmol Vis Sci. 1976; 15: 538-41.

8. Robbins SG, Detrick B, Hooks JJ. Ocular tropisms of murine coronavirus (strain JHM) after inoculation by various routes. Invest Ophthalmol Vi Sci. 1991; 32(6): 1883-93.

9. Alert: Important coronavirus updates for ophthalmologists. American Academy of Ophthalmology. https://www.aao.org/headline/ alert-important-coronavirus-context. (Access 17.03.2020).

10. Prystupa A. Wpływ wybranych leków stosowanych ogólnie na zmiany w narządzie wzroku. In: Prost M, Jachowicz R, Nowak JZ (ed). Kliniczna farmakologia okulistyczna. $2^{\text {nd }}$ ed. Edra Urban \& Partner, Wrocław 2016: 361-71.

11. Junk AK, Chen PP, Lin SC et al. Disinfection of Tonometers. A Report by the American Academy of Ophthalmology. Ophthalmology. 2017; 124(12): 1867-75.

Konflikt interesów:

Nie występuje.

Finansowanie:

Nie występuje.

Etyka:

Treści przedstawione w artykule są zgodne z zasadami Deklaracji Helsińskiej,

dyrektywami EU oraz ujednoliconymi wymaganiami dla czasopism biomedycznych.
Conflict of interest:

None.

Financial support:

None.

Ethics:

The content presented in the article complies with the principles of the Helsinki Declaration, EU directives and harmonized requirements for biomedical journals. 